\title{
Factors Affecting Savings Deposit Decision of Individual Customers: Empirical Evidence from Vietnamese Commercial Banks
}

\author{
Bui Nhat VUONG ${ }^{1}$, Dao Duy TUNG ${ }^{2}$, Ha Nam Khanh GIAO ${ }^{3}$, Ngo Tan DAT ${ }^{4}$, Tran Nhu QUAN ${ }^{5}$
}

Received: April 26, 2020 Revised: May 03, 2020 Accepted: June 07, 2020

\begin{abstract}
Capital mobilization is a traditional business of commercial banks and is one of the core foundations for the development of a bank. Capital mobilization is the main input in the operation of a bank, and this is also the basis for generating output for credit activities as well as other banking activities. This study aims to determine the main factors that affect the decisions of individual customers to put savings deposit in Vietnamese commercial banks. Survey data collected from 403 individual customers were analyzed to provide evidence. The results from the multiple regression analysis by using SPSS software revealed that all scales in this study were reliable, and there were six components impacting the savings deposit decision of individual customers from the strongest to the weakest in the following order: the form of promotion, bank brand, service quality, interest rate policy, and employee knowledge and attitude. Besides, the finding showed customers who have high income tend to have a stronger decision on savings deposits in commercial banks. The main findings of this article provide some empirical implications for marketers in banks and serve as a suggestion to improve these factors in order to retain and attract individual customers' savings deposit decisions.
\end{abstract}

Keywords : Capital Mobilization, Marketing Promotion, Bank Brand, Service Quality, Interest Rate, Savings Deposit, Vietnam

JEL Classification Code: G21, G41, M31

\section{Introduction}

In recent years, the Vietnam banking system has been restructuring to improve the quality of operation, and the banking administrators need to have a new perspective on the domestic financial market due to the massive penetration

${ }^{1}$ First Author and Corresponding Author. Lecturer, Faculty of Labor Relations and Trade Unions, Ton Duc Thang University, Vietnam [Postal Address: No.19, Nguyen Huu Tho Street, Tan Phong Ward, District 7, Ho Chi Minh City, 756600, Vietnam]

Email: buinhatvuong@tdtu.edu.vn

2Lecturer, Faculty of Business Administration, Tay Do University, Vietnam. Email: howie@tungdao.net

${ }^{3}$ Dean, Faculty of Air Transport, Vietnam Aviation Academy, Ho Chi Minh City, Vietnam. Email: khanhgiaohn@yahoo.com

${ }^{4}$ Lecturer, Faculty of Labor Relations and Trade Unions, Ton Duc Thang University, Vietnam. Email: tandat.hospitality@gmail.com

${ }^{5}$ Lecturer, School of Business, International University-Vietnam National University HCMC, Vietnam. Email: tnquan@hcmiu.edu.vn

(C) Copyright: The Author(s)

This is an Open Access article distributed under the terms of the Creative Commons Attribution Non-Commercial License (http://Creativecommons.org/licenses/by-nc/4.0/) which permits unrestricted noncommercial use, distribution, and reproduction in any medium, provided the original work is properly cited. of foreign banks. The amounts of savings deposits of banks significantly decrease, and capital mobilization has been more difficult due to the mentioned reasons (Vuong $\&$ Suntrayuth, 2020). The competition of the joint-stock commercial banks, foreign banks, and the state banks of Vietnam has been increasingly fierce when Vietnam's economy gradually stabilized. Although facing numerous difficulties, the potential development of the country's banking industry is undeniable. The economic growth rate is relatively high compared to the region and the world; Vietnam is considered a very potential market.

Moreover, the market extension opportunity created by the international economic integration and commercial banks has many good conditions to apply updated technologies and gain more management experience of foreign banks (Tabash, 2019). International integration also plays a major role in the constant improvement of factors, especially in a management capacity, quality of human resources, and technology to establish a sustainable platform when the country integrates into the international economy extensively. The economy of Vietnam is increasingly developing, and the amount of capital needed 
for production and business activities of the economy is also growing. Thus, the bank's deposit mobilization activities also need to increase accordingly. All commercial banks always have the specific planning of deposit mobilization for each period, objectively and practically, to achieve high efficiency. It means that the deposits must meet the requirements of the bank with the lowest cost, and acceptable risks (Banna, Ahmad, \& Koh, 2017). In addition, the depositors' demands are increasingly diverse, requiring bank administrators to study the markets and factors affecting the customer's savings deposit decision, thus regaining ex-customers, introducing the methodology to keep the existing customers, and determining the potential customer for the future (Lokesha \& Hawaldar, 2019).

The research of the factors for the deposit decision of customers plays a crucial role in the business strategy of banks. It also provides an insight view of the market and the diversified demands of customers. There are some solutions that aim to satisfy the customer's demand and achieve the set goals through the study. From such realization, the objective of the study is to figure out which factors are affecting the savings deposit decisions at the commercial banks and to propose some administrative implications to attract more individual customers to put one's savings in the deposit.

\section{Literature Review}

\subsection{Savings Deposit}

Deposits are defined as funds placed in a financial institution by economic surplus units such as householders, corporations, investors, and government. These funds can either be from cash, claims to money, like checks placed in depositor's accounts, bank loans, or money from investments (van Dahm, 1995). Savings deposit is a part of the income of the current year, and it is not used for consumption purposes. This is the deposit of a third party that may withdraw at any time and can only do so under certain conditions, including forms of cash savings, savings books, and identity cards. Ahmed (2010) defines deposits as funds that customers place with a bank and that the bank is obligated to repay on demand, after a specific period of time or after the expiration of some required notice period. Deposit is the primary funding source for most banks and, as a result, has a significant effect on a bank's liquidity. Thus, mobilization of deposits for a bank is as essential as oxygen for human beings. According to Audu et al. (2015), bank owners are more interested in sourcing deposits by any means possible. They also observed that banks often set an impossible target for the staff in the marketing department, thus marketing becoming the most important function in the banks.

\subsection{Savings Deposit Decision}

The customers experience a complicated shopping process when they make a decision to select a suitable service to satisfy their demand. The process of selection, usage, and evaluation of banking services usually consist of three different stages: the pre-purchase stage, the service implementation, and the post-purchase stage (Kieu, 2009).

The period of pre-selection to open a savings deposit account, the perception of demand: practical considerations when you are selecting a bank such as how can this idle money be the safest to earn the highest profit? Which is the most suitable category to invest in? Searching data: figure out the information to invest your idle money. Which bank should you select if you decided to open a savings account? Why choose this bank to deposit and not another bank? Banking evaluation and selection: the subjective perception of the customer has a significant impact on the bank selection to open a deposit account. The perception could be formed in the past such as bank brand reputation, the impact of relatives, interest rate, bank promotion, etc.

The bank selection period to make savings deposits: when you have selected a bank to deposit money, the following factors that affect customers are the service requirements from the bank and which bank is committed to transfer the transactions. In other words, the savings behavior of customers is sensitive to the service element that the bank provides. In fact, customers who bring money to the bank to save are rarely transferred to other banks because of the level of safety in transporting money.

The post period after opening a savings deposit account: to attract returning customers to the bank, become loyal customers, and introduce to others once they have experienced the service that the bank offers, depending on the procedures of the provided services, the image as well as the professional standards of bank employees. The deposit behavior of the customer is established by two components: internal and external. The external component is expressed through the act of selecting the bank, the act of choosing the type of money to deposit, the term of deposit account, and the type of bank savings. (1) The bank selection of customers depends on the bank's reputation and the convenience of a safety factor, and the interest rate is from the expedient (profit) incentive. (2) Selecting the Vietnamese currency or foreign currency to earn higher benefits. (3) From the motive of safety, benefits, and convenience, it is advisable to choose a short or long term, and the type of savings account will bring the highest benefits. The internal component comes from three factors: (1) the motive; (2) the economic environment factors expressed by inflation rate, gold market, foreign exchange market, stock market, and real estate market; and (3) the bank's reputation, marketing activities, and customer service policies. 


\section{Hypothesis Development}

Based on the theoretical research, the authors have looked at the model of the theory of consumer behavior. They have selected models in many Asian countries, including from a number of studies regarding the savings deposit decision. Besides, the research is based on empirical studies that are related to the savings deposits of individual customers. Based on the same research decision to deposit money, this will provide a solid theoretical basis, helping to research and apply the model in accordance with the research conditions at joint-stock commercial banks in Vietnam. Also, based on qualitative research results, two-thirds of the discussion group agreed on six factors: (1) Bank brand, (2) Interest rate policy, (3) Convenience, (4) Service quality, (5) Form of promotion, and (6) Employee knowledge and attitude. These are sufficient to influence the decision of individual customers to deposit savings money at commercial banks in Vietnam (see Figure 1).

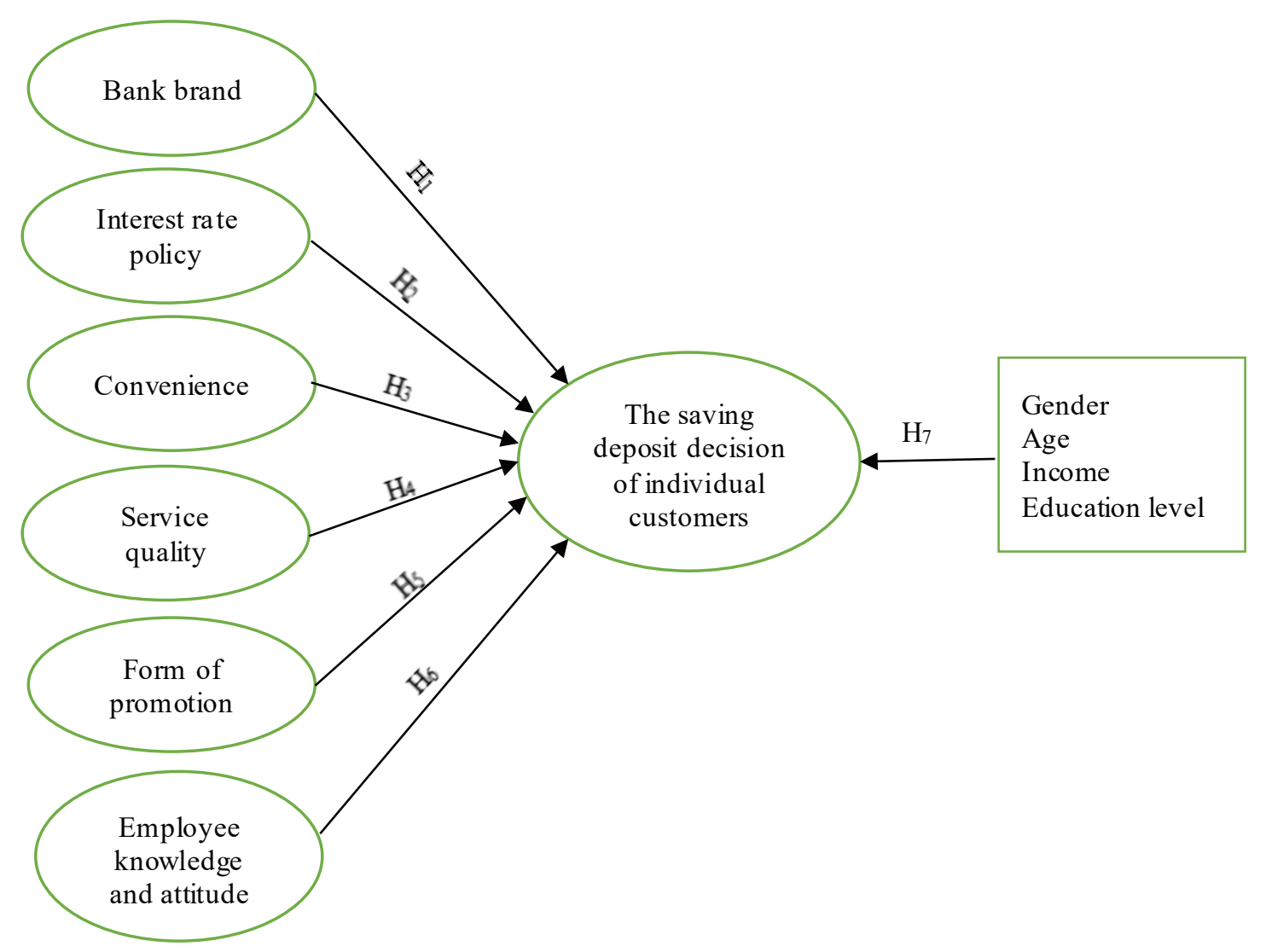

Figure 1: The conceptual model

\subsection{Bank Brand}

Bank brand is the image of the bank in the hearts of the customers, the trust of customers in the bank, an intangible asset, but the most valuable in the operation of the bank. From the features of bank activities that are based on public trust, the more the bank's brand is known and trusted, the more favorable the capital mobilization of the bank will be. The reputation of each bank is built and formed through a long process. Depositors often choose older banks rather than newly-established banks. The big banks are often preferred over small banks. Therefore, when the bank has built a strong and reputable brand, it will have an advantage in raising capital for a long time. Jaber and Manasrah (2017) and Krisnanto (2011) showed a positive relationship between bank brand and individual customer's decision to deposit savings.

Hypothesis $\mathrm{H}_{1}$ : Bank brand has a positive $(+)$ impact on individual customers' decision to deposit savings at a jointstock commercial bank in Vietnam.

\subsection{Interest Rate Policy}

The deposit interest rate is the interest rate that the bank must pay to the customers who deposit funds in the bank. 
It is used to calculate the interest the bank has to pay to the customer. The deposit interest rate has a vital role in affecting deposit mobilization results in a large-scale and capital structure. The increase or decrease of the deposit interest rate of the commercial bank depends on the business strategy of each bank. In addition to covering all operating costs, the bank interest rates need to reflect the supply-demand relationship of money in the market, closely following inflation fluctuations, and must have market competitiveness. Vazifehdoost et al. (2015), and Mushtaq and Siddiqui (2017) indicated a positive relationship between interest rate policy and individual customer savings decisions. Therefore, we have the hypothesis $\mathrm{H} 2$ as follows:

Hypothesis $\mathrm{H}_{2}$ : Interest rate policy has a positive $(+)$ effect on the decision of individual customers to save money at a joint-stock commercial bank in Vietnam.

\subsection{Convenience}

Convenience refers to the bank's facilities; it contributes to building the bank's image in the customers' eyes. A bank which has good technical facilities, amenities, and convenient and safe transaction locations will help customers feel more secure when depositing money into the bank, creating a premise to be able to serve customers quickly and effectively, thereby contributing to create credibility with customers and enhance their ability to attract customers. Technical and material facilities include fixed assets such as offices, networks of branches, transaction points, equipment, and facilities for banking operations, information systems, and banking technology. Vazifehdoost et al. (2015) and Krisnanto (2011) showed a positive relationship between convenience and individual client's decision to save money. From there, we have the hypothesis $\mathrm{H} 3$ as follows:

Hypothesis $\mathrm{H}_{3}$ : Convenience has a positive $(+)$ impact on individual customers' decision to deposit savings at a jointstock commercial bank in Vietnam.

\subsection{Service Quality}

Service quality is the service capacity provided by a bank and is reflected in the satisfaction of customers' needs and desires. The quality of service is therefore perceived by the customer, and not decided by the bank. Customers assess the quality of banking services through aspects such as processes, procedures, transaction times, and complaints from customers. Jaber and Manasrah (2017) showed a positive relationship between service quality and individual customer's savings decisions. From there, we have the hypothesis $\mathrm{H} 4$ as follows:
Hypothesis $\mathrm{H}_{4}$ : Service quality has a positive $(+)$ impact on individual customers' decision to deposit money at jointstock commercial banks in Viet Nam.

\subsection{Form of Promotion}

Marketing plays an increasingly important role nowadays, especially in the banking sector. It has become one of the factors that directly influence the customer's deposit decision. If the depositor has a good feeling and is interested in the advertising program of a certain product or bank brand, they will first identify that bank brand and select it from other products and other competing brands, and when they have demand, the ability to choose for the products or brand is very high. Based on the psychology of customers, banks have constantly launched rich and diverse promotions to attract customers. Promotion programs are advertised in many places such as television, banners, etc., to attract customers. When there is a high demand for capital attraction, there is a strong competition to gain market share among banks, the promotion activities become more and more aggressive. Promotions contribute to the customer's decisions because if the bank puts out impressive promotions, creating benefits for customers, it will attract customers' attention. Giao (2019) showed a positive relationship between the form of promotion and the decision to deposit savings money of individual customers. From there, we have the hypothesis $\mathrm{H} 5$ as follows:

Hypothesis $\mathrm{H}_{5}$ : The form of promotion has a positive $(+)$ effect on the decision to deposit money of individual customers at a joint-stock commercial bank in Vietnam.

\subsection{Employee Knowledge and Attitude}

A bank employee is the representative of the bank's image. Therefore, to increase capital mobilization, it is extremely important that bank employees must meet the criteria of a professional banker: customer knowledge, business knowledge, process knowledge, and perfect service style. Besides, the attitude of employees when communicating with customers is also very important, it makes a very strong first impression on customers. A good, standardized, and professional service attitude can attract customers to the bank, otherwise, it can lose customers, causing serious results in the bank's operations, first of all in the capital mobilization process. Krisnanto (2011) showed a positive relationship between bank employees and individual customers' decisions on deposit savings. From there, we have the hypothesis $\mathrm{H} 6$ as follows:

Hypothesis $\mathrm{H}_{6}$ : The bank employee has a positive $(+)$ effect on the decision of the individual customer to save money at a joint-stock commercial bank in Vietnam. 
Hypothesis $\mathrm{H}_{7}$ : Control variables (e.g., gender, age, income, educational level) influence the decision of the individual customer to save money at a joint-stock commercial bank in Vietnam.

\section{Research Methods}

All the variables in the model were measured with multiple items, which were developed by other researchers, to adequately capture the domain of constructs. The survey questionnaire was originally designed in English and then translated into Vietnamese by the researcher with the support of some English experts and banking experts. To conduct qualitative research, the Vietnamese version of the survey questionnaire was pre-tested using in-depth interviews with some customers who have savings deposit at a joint-stock commercial bank in Vietnam. The in-depth interviews were conducted with 10 respondents (six banking experts and four customers) to ensure that the final questions would be well understood and valuable in measuring observed variables before launching the main survey. The detailed questionnaire was shown to interviews for checking their understanding. During the interview, the author also wanted to find out if the chosen measurement scale was suitable for conducting the research in Vietnam. All the comments from the interviewees were gathered with the aim to modify the measurement scale. Based on the feedback of respondents, the survey questionnaire was slightly modified to make it clearer and more understandable.

After the pilot study, questionnaires were used for the survey in large numbers. The results of the pilot test proved the good design of questionnaires, and they were used in the main survey. Twenty-seven items are measured on a fivepoint Likert scale, where $1=$ strongly disagree, $2=$ disagree, $3=$ neutral, $4=$ agree, $5=$ strongly agree. The survey involved 424 individual customers depositing savings at a joint-stock commercial bank in Vietnam. After eliminating unsatisfactory questionnaires (incomplete answers, answers with two or more options), there remained 403 valid surveys, reaching $95.05 \%$. The author categorized 403 individual customers surveyed by gender, age group, income, and education level (see Table 1).

\section{Empirical Results and Discussion}

\subsection{The Assessment of Reliability and Validity}

The scale was first analyzed for Cronbach's Alpha reliability coefficient; variables with an item-total correlation less than 0.3 will be rejected and the scale will be accepted for analysis in the following steps when Cronbach's Alpha's reliability is from 0.7 and above (Giao \& Vuong, 2019). Overall, Cronbach's Alpha results of the scale were
Table 1: The customer characteristics

\begin{tabular}{|l|c|c|c|}
\hline \multirow{2}{*}{\multicolumn{2}{|c|}{$\mathbf{N}=\mathbf{4 0 3}$}} & Frequency & $\begin{array}{c}\text { Percentage } \\
(\%)\end{array}$ \\
\hline \multirow{4}{*}{ Gender } & Female & 198 & 49.1 \\
\cline { 2 - 4 } & Male & 205 & 50.9 \\
\hline \multirow{4}{*}{ Age } & $18-25$ years old & 39 & 9.7 \\
\cline { 2 - 4 } & $26-35$ years old & 129 & 32.0 \\
\cline { 2 - 4 } & $36-45$ years old & 151 & 37.5 \\
\cline { 2 - 4 } & $>45$ years old & 84 & 20.8 \\
\hline \multirow{4}{*}{ Income } & $<5$ million & 32 & 7.9 \\
\cline { 2 - 4 } & $5-10$ million & 173 & 42.9 \\
\cline { 2 - 4 } & $10-15$ million & 146 & 36.2 \\
\cline { 2 - 4 } & $>15$ million & 52 & 12.9 \\
\hline \multirow{4}{*}{$\begin{array}{l}\text { Education } \\
\text { Level }\end{array}$} & High school & 79 & 19.6 \\
\cline { 2 - 4 } & College & 63 & 15.6 \\
\cline { 2 - 4 } & Bachelor & 232 & 57.6 \\
\cline { 2 - 4 } & Postgraduate & 29 & 7.2 \\
\hline
\end{tabular}

from 0.794 to 0.989 and most correlation coefficients of total variables observed in the scale were greater than 0.3 (see Table 2). However, the FOP1 item had a correlation coefficient of less than 0.3 , thus the author rejected this variable from the analysis model. After the rejection of the FOP1 variable, all observed variables of this scale had a total correlation coefficient greater than 0.3 . So, they were used for subsequent exploratory factor analysis (EFA).

Table 2: The result of reliability

\begin{tabular}{|l|c|c|c|c|}
\hline \multicolumn{1}{|c|}{ Scale } & Code & Items & $\begin{array}{c}\text { The } \\
\text { Cronbach's } \\
\text { alpha } \\
\text { minimum } \\
\text { value of } \\
\text { Corrected } \\
\text { item-total } \\
\text { Correlation }\end{array}$ \\
\hline Bank brand & BB & 3 & 0.841 & 0.661 \\
\hline $\begin{array}{l}\text { Interest rate } \\
\text { policy }\end{array}$ & IRP & 3 & 0.867 & 0.700 \\
\hline Convenience & CON & 4 & 0.794 & 0.515 \\
\hline Service quality & SQ & 5 & 0.839 & 0.531 \\
\hline $\begin{array}{l}\text { Form of } \\
\text { promotion }\end{array}$ & FOP & 4 & 0.909 & 0.725 \\
\hline $\begin{array}{l}\text { Employee } \\
\text { knowledge and } \\
\text { attitude }\end{array}$ & EKA & 5 & 0.865 & 0.587 \\
\hline $\begin{array}{l}\text { Saving deposit } \\
\text { decision }\end{array}$ & SDD & 3 & 0.830 & 0.642 \\
\hline
\end{tabular}


Table 3: The validity of variables in the second time

\begin{tabular}{|c|c|c|c|}
\hline Construct & Observed variables & Code & $\begin{array}{l}\text { Factor } \\
\text { loading }\end{array}$ \\
\hline \multirow{5}{*}{$\begin{array}{l}\text { Employee knowledge } \\
\text { and attitude }\end{array}$} & Employees have professional job manipulation & EKA3 & 0.840 \\
\hline & Employees are polite & EKA4 & 0.828 \\
\hline & Employees are welcoming and friendly & EKA2 & 0.824 \\
\hline & Employees guide detailed procedures & EKA1 & 0.705 \\
\hline & Employees are dynamic and beautiful & EKA5 & 0.683 \\
\hline \multirow{4}{*}{ Form of promotion } & I can easily update new product information & FOP3 & 0.823 \\
\hline & Products meet my requirements & FOP4 & 0.797 \\
\hline & This bank has attractive promotions & FOP5 & 0.788 \\
\hline & This bank has policies to give gifts to me on New Year and birthday & FOP2 & 0.763 \\
\hline \multirow{5}{*}{ Service quality } & The transaction process at this bank is simple and easy to understand & SQ1 & 0.737 \\
\hline & Transaction time at this bank is fast and convenient & SQ2 & 0.727 \\
\hline & This bank has diversified transaction channels (telephone, internet ...) & SQ3 & 0.723 \\
\hline & Transaction procedures are flexible & SQ5 & 0.654 \\
\hline & This bank resolves complaints quickly and satisfactorily & SQ4 & 0.630 \\
\hline \multirow{3}{*}{ Interest rate policy } & Savings interest rates at this bank are competitive in the market & IRP2 & 0.911 \\
\hline & $\begin{array}{l}\text { Savings interest rates of this bank are flexible according to each } \\
\text { savings product }\end{array}$ & IRP1 & 0.889 \\
\hline & $\begin{array}{l}\text { Interest rates of savings deposits of this bank are publicly and clearly } \\
\text { disclosed }\end{array}$ & IRP3 & 0.863 \\
\hline \multirow{3}{*}{ Bank brand } & It is a well-known bank & BB2 & 0.796 \\
\hline & It is a reputable bank & BB3 & 0.777 \\
\hline & It has a long history in the area & BB1 & 0.762 \\
\hline \multirow{3}{*}{ Convenience } & This Bank's branches (branches, transaction offices) are widespread & CON1 & 0.832 \\
\hline & This Bank's transaction location is convenient, safe for customers & CON2 & 0.747 \\
\hline & The facilities of this bank are modern and comfortable & CON3 & 0.663 \\
\hline \multirow{3}{*}{$\begin{array}{l}\text { Saving deposit } \\
\text { decision }\end{array}$} & This bank is always the first choice when I deposit money & SDD3 & 0.888 \\
\hline & I have complete peace of mind when depositing money at this bank & SDD2 & 0.870 \\
\hline & I would recommend this bank to relatives and friends & SDD1 & 0.834 \\
\hline \multicolumn{3}{|l|}{ Eigenvalue } & 1.059 \\
\hline \multicolumn{3}{|c|}{ Accumulated Variance Extracted \% } & 71.371 \\
\hline \multicolumn{3}{|l|}{$\mathrm{KMO}$} & 0.897 \\
\hline \multicolumn{3}{|l|}{ P-value of Bartlett's Test } & 0.000 \\
\hline
\end{tabular}


The outcome of the first factor analysis showed that $\mathrm{KMO}$ and Bartlett's tests produced $\mathrm{KMO}$ coefficient $=0.993$ $(>0.5)$; Sig. $=0.000($ Sig. $<0.05)$. This result indicated that the observed variables were correlated and the EFA factor analysis was appropriate. With eigenvalues greater than 1 and with principal components extraction and varimax rotation, the factor analysis extracted seven elements from 24 observed variables and with a total variance extracted of $70.207 \%$ (greater than 50\%). However, the factor loading of variable CON4 was less than 0.5 , thus this variable is excluded from the scale of the Convenience factor.

After the elimination of the CON4 variable, the authors conducted the second factor analysis (see Table 3). The analysis results showed that the total variance extracted was $71.371 \%$ (greater than 50\%). KMO coefficient reached 0.897 (greater than 0.5 and less than 1). Bartlett's test had Sig. = 0,000 (less than 0.05). The eigenvalue coefficient was 1.059 (greater than 1). These indicators were satisfactory, and the load factor of the observed variables was greater than 0.5 . This result indicated that the observed variables in the whole were correlated and the EFA factor analysis was appropriate. Thus, the scales met the reliable and valid requirements.

\subsection{Correlation Analysis}

Before conducting the regression analysis, the author used the Pearson correlation coefficient to quantify the degree of rigidity of the linear relationship between two variables (Vuong \& Giao, 2020). In the Pearson correlation analysis, there is no distinction between independent and dependent variables; all variables are considered equal. However, if the variables are strongly correlated, the multicollinearity problem must be considered after regression analysis. Based on Table 4, the Pearson correlation analysis results indicated that the significance level of the coefficients is very small (sig. $=0<0.05)$. Therefore, the correlation coefficients

Table 4: Matrix Pearson correlation coefficient

\begin{tabular}{|l|c|c|c|c|c|c|c|}
\hline & BB & IRP & CON & SQ & FOP & EKA & SDD \\
\hline BB & 1 & $0.535^{* *}$ & $0.567^{* *}$ & $0.552^{* *}$ & $0.541^{* *}$ & $0.282^{* *}$ & $0.470^{* *}$ \\
\hline IRP & & 1 & $0.516^{* *}$ & $0.481^{* *}$ & $0.528^{* *}$ & $0.204^{* *}$ & $0.439^{* *}$ \\
\hline CON & & & 1 & $0.600^{* *}$ & $0.580^{* *}$ & $0.288^{* *}$ & $0.466^{* *}$ \\
\hline SQ & & & & 1 & $0.594^{* *}$ & $0.461^{* *}$ & $0.496^{* *}$ \\
\hline FOP & & & & & 1 & $0.417^{* *}$ & $0.549^{* *}$ \\
\hline EKA & & & & & & 1 & $0.344^{* *}$ \\
\hline SDD & & & & & & & 1 \\
\hline
\end{tabular}

Note: $\mathrm{BB}=$ bank brand; IRP = interest rate policy;

$\mathrm{CON}$ = convenience; $\mathrm{SQ}$ = service quality; $\mathrm{EKA}=$ employee knowledge and attitude; SDD = saving deposit decision.

${ }^{* *}=p<0.001$ were statistically significant and were eligible to include regression analysis.

\subsection{Regression Analysis}

The scale of factors that affect the savings deposit decision has been considered a linear correlation. The authors continued using the regression analysis to examine the relationship between the factors affecting the savings deposit decision of individual customers. The adjusted $\mathrm{R}^{2}$ value of 0.676 meant that $67.6 \%$ of the variation of the savings deposit decision was explained by the variation of five independent variables such as BB, SQ, FOP, EKA, IRP (see Table 5). The F-test used in variance analysis (Anova) was a hypothesis test of the suitability of the overall linear regression model. The analysis shown in Table 5 reflected that the F-value was significant for Sig. $=0.000(<0.05)$ and it meant the linear regression model was consistent with the actual collected data, and the included variables were statistically significant at the 5\% significance level. Besides, the DurbinWatson test indicated that $\mathrm{d}=1.685(1<\mathrm{d}<3)$, thus the authors concluded that the residues were independent of each other or they did not correlate between the residuals (Vuong et al., 2020). Moreover, the VIF (Variance Inflation factor) magnification factor reached the maximum value of 2.123 (less than 5) and these independent variables are not closely related to each other, thus there was no multicollinearity (Giao et al., 2020).

Table 5: Statistical analysis of regression coefficients

\begin{tabular}{|c|c|c|c|c|c|c|c|}
\hline $\begin{array}{l}\text { Hypoth- } \\
\text { esis }\end{array}$ & \multicolumn{3}{|c|}{ Relationship } & \multirow{2}{*}{\begin{tabular}{c|} 
Beta \\
0.128 \\
\end{tabular}} & \multirow{2}{*}{\begin{tabular}{|c|} 
Sig. \\
0.017 \\
\end{tabular}} & \multirow{2}{*}{\begin{tabular}{|c|} 
VIF \\
1.837 \\
\end{tabular}} & \multirow{2}{*}{$\begin{array}{c}\text { Result } \\
\text { Supported }\end{array}$} \\
\hline $\mathrm{H}_{1}$ & $\mathrm{BB}$ & $\rightarrow$ & SDD & & & & \\
\hline $\mathrm{H}_{2}$ & SQ & $\rightarrow$ & SDD & 0.123 & 0.033 & 2.123 & Supported \\
\hline $\mathrm{H}_{3}$ & FOP & $\rightarrow$ & SDD & 0.259 & 0.000 & 2.031 & Supported \\
\hline $\mathrm{H}_{4}^{3}$ & EKA & $\rightarrow$ & SDD & 0.096 & 0.037 & 1.338 & orted \\
\hline $\mathrm{H}_{5}^{4}$ & IRP & $\rightarrow$ & SDD & 0.111 & 0.030 & 1.671 & Supported \\
\hline $\mathrm{H}_{6}$ & $\mathrm{CON}$ & $\rightarrow$ & SDD & 0.085 & 0.127 & 1.979 & $\begin{array}{c}\text { Not } \\
\text { Supported }\end{array}$ \\
\hline \multicolumn{8}{|c|}{ Control variables } \\
\hline $\mathrm{H}_{7 \mathrm{a}}$ & Gen & $\rightarrow$ & SDD & -.022 & .664 & 1.033 & $\begin{array}{c}\text { Not } \\
\text { Supported }\end{array}$ \\
\hline $\mathrm{H}_{7 \mathrm{~b}}$ & Age & $\rightarrow$ & SDD & -.065 & .261 & 1.361 & $\begin{array}{c}\text { Not } \\
\text { Supported }\end{array}$ \\
\hline $\mathrm{H}_{76}$ & Inc & $\rightarrow$ & SDD & .206 & .002 & 1.803 & Supported \\
\hline $\mathrm{H}_{7 \mathrm{~d}}$ & Edu & $\rightarrow$ & SDD & -.023 & .697 & 1.369 & $\begin{array}{c}\text { Not } \\
\text { Supported }\end{array}$ \\
\hline \multicolumn{8}{|c|}{$\begin{array}{l}\text { Adjusted R Square: } 0.676 \\
\text { The F-statistic in (ANOVA): } 41.287 \\
\text { (Sig. of ANOVA): } 0.000 \\
\text { Durbin-Watson: } 1.685\end{array}$} \\
\hline
\end{tabular}

Note: $\mathrm{BB}=$ bank brand; IRP = interest rate policy;

$\mathrm{CON}=$ convenience; $\mathrm{SQ}=$ service quality;

$\mathrm{EKA}=$ employee knowledge and attitude;

SDD = saving deposit decision; Gen = gender;

Inc = income; Edu = educational level. 
Therefore, the relationship between the independent variables did not significantly affect the analysis of the results of the regression model. The standardized regression equation as the following:

$$
\begin{aligned}
& \mathrm{SDD}=0.128 * \mathrm{BB}+0.111 * \mathrm{IRP}+0.123 * \mathrm{SQ}+0.259 * \mathrm{FOP} \\
& +0.096 * \mathrm{EKA}
\end{aligned}
$$

Regression coefficients had positive signs $(+)$, which showed independent variables were positively related to the dependent variables. The savings deposit decision was remarkably impacted in the following declining order: Form of promotion $\left(\beta_{5}=0.259\right)$, Bank brand $\left(\beta_{1}=0.128\right)$, Quality of service $\left(\beta_{4}=0.123\right)$, Interest rate policy $\left(\beta_{2}=\right.$ $0.1111)$, and Employee knowledge and attitude $\left(\beta_{6}=0.096\right)$. Thus, hypotheses $\mathrm{H}_{1}, \mathrm{H}_{2}, \mathrm{H}_{4}, \mathrm{H}_{5}, \mathrm{H}_{6}$ were accepted at the 95\% confidence level. However, the Convenience variable had no effect on the savings deposit decision because the statistical Sig $=0.127>0.05$. At the same time, the authors conducted a test of the difference in the decision to send money according to personal characteristics. The outcomes of the discrepancy test showed that income influences the savings decision ( $p$-value $=0.002<0.05$ ). Besides, the test results had not found the relationship of gender, age group, and educational level with the savings deposit decision of individual customers ( $p$-value $=0.664 ; 0.261 ; 0.697$, respectively, more than 0.05 ) (see Table 5).

\section{Conclusion and Recommendation}

\subsection{Conclusion}

Based on the theeoretical overview, a research model has been developed for this study. This model has been conducted with a sample size of 403 individual customers saving at the Joint Stock Commercial Bank in Vietnam. With the results obtained, this study contributed positively to practical management, specifically as follows: the research results indicated that the entire scale used in the study is credible (Cronbach's Alpha > 0.7), thus they can be used for other studies. Regarding the factors affecting the savings deposit at joint-stock commercial banks in Viet Nam, the study identified six components impacting the deposit decision, in the following order from the strongest to the weakest: the form of promotion, income, bank brand, quality of service, interest rate policy, and employee knowledge and attitude (Figure 2).

\subsection{Recommendation}

\subsubsection{Form of Promotion}

"Form of promotion" is the factor that has the most influence $(\beta=0.259)$ on the savings deposit decision of individual customers. Today, as information technology

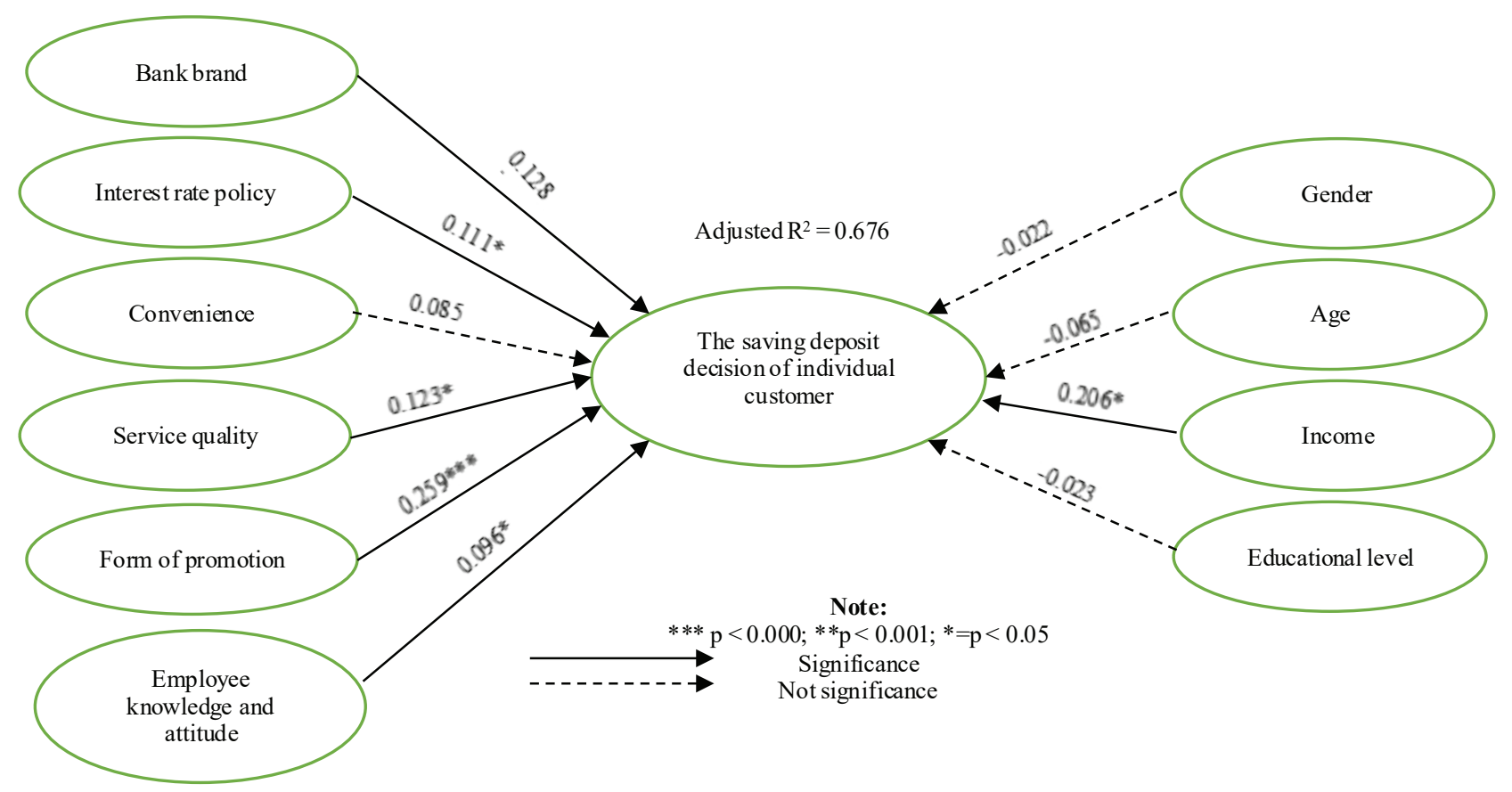

Figure 2: The OLS model 
increasingly develops, banks should take advantage of the Internet and Facebook to promote advertisements and design a beautiful website. The information on website updates along with the use of interesting images will attract customers' attention when logging into the website. There will be a hotline on the bank's website, which will ensure customer service 24/24. Also, the bank needs to regularly organize customer meetings and conferences to discuss customers' expectations and capture the best needs to satisfy customers. Besides, it should periodically investigate the customers' response to the form of savings deposits mobilization in the last time. From the customers' feedbacks, the bank could gain more experience and understand costumers' needs.

\subsubsection{Personal Characteristics (Income)}

Based on the result of testing the difference according to individual characteristics, the study found that the income is the second most influential factor $(\beta=0.202)$ on individual customers' decisions in making a deposit. Customers with high and stable income are often interested in interest rates, if any bank has more favorable offers than the others, they will change to them. Hence, to this group of customers, the bank should proactively provide information on interest rates and associated incentive policies for them to choose. With customers who have regular, but not high income, and who want to accumulate for a future plan, depending on the purpose of the deposit, the bank will instruct them on the appropriate products. This action shows enthusiasm for the depositors and it is one of the ways to attract customers as most of the official workers are people who have many plans, but their immediate income is not high.

\subsubsection{Bank Brand}

"Bank brand" is the third most influential factor $(\beta=0.128)$ on the decision to deposit money of individual customers. The bank needs to promote the bank image well, improve the position of the bank in the best way through the media, community activities, sponsors, etc. Banks need to build a representative product and service to dominate the market, become a leader in that product or service area. This method also brings the bank's brand closer to customers. Besides, the bank needs to organize brand training for all bank staff, through which the staff will be a brand ambassador. Each employee must be aware that their actions have an effect on the brand reputation of the bank. Banks also need to research and develop greetings slogan to create their own identities.

\subsubsection{Service Quality}

"Service quality" is the fourth most influential factor $(\beta=0.123)$ on the decision of the individual customers to deposit money. The bank should conduct a prompt revision and modification of procedures and regulations that are no longer suitable to the reality so that customers can access banking services easily, conveniently with shortening transaction time. Also, it is necessary to improve the qualifications of staff who directly provide deposit services to customers. Bank staff must understand and master the products and utilities to advise and persuade customers. Besides, the employe should also be equipped with soft skills to provide deposit services such as communication skills, persuasion skills, negotiation skills, and sales skills. Banks need to develop and innovate with modern technologies and continue to invest in upgrading computer systems and information technology infrastructure. Promoting the application of software according to international standards will complement executive management work. The application of new technology will contribute to shortening transaction time, reducing risks, and ensuring information confidentiality.

\subsubsection{Interest Rate Policy}

"Interest rate policy" is the fifth most influential factor $(\beta$ $=0.111$ ) on the decision of individual customers to deposit money. The bankneeds to issue flexible interestrate policies for each different term in accordance with its goals. Specifically, for customers who do not need capital immediately, banks should encourage customers to save money in the long term to enjoy higher interest rates and this is also a fixed amount of capital for benefit of the bank. Customers who need to use capital flexibly should be advised to save money in the short term so that customers can easily withdraw capital to implement their plans while ensuring capital safety. Besides, the bank should assign branches to proactively decide, negotiate deposit rates, and lend at their units, increase competitiveness, and attract customers.

\subsubsection{Employee Knowledge and Attitude}

Bank staffs are the factor that has the lowest impact on individual customers' decisions in making a deposit. The bank needs to have a medium-to-long-term strategy of recruitment and re-training. Building a scientific, accurate recruitment process in order to recruit employees who are qualified and suitable. It is needed to professionally re-train staff to create human resources that are sufficient to meet the work demands in a high-tech environment. Banks need to regularly open classes of communication, customer skills to improve their customer services. Employees must be the one who creates a friendly, safe, and happy atmosphere for customers when they come to the bank to make transactions. It is necessary to practice the habit of greetings and not forget to thank customers for their choices and consideration for the bank. 


\section{Limitation}

Although this study fulfilled the research objectives, there are some limitations. Firstly, the study was only conducted with 403 individual customers at joint-stock commercial banks in Vietnam with a convenience sampling method, the results of the study were only related to private banks and the results may vary for other banks (e.g., public or foreign banks). Further research should be conducted with different types of banks, with a probability sampling method to achieve more representative results. At the same time, it is necessary to expand the survey subjects to corporate customers, to get an overall picture of the bank's capital mobilization. Secondly, this study only explained $67.6 \%$ of the variation of savings deposit decisions through six independent variables. Thus, several other factors are affecting the decision to deposit savings at a joint-stock commercial bank in Vietnam that have not been found by the research. Further research needs to add more factors.

\section{References}

Ahmed, J. U.-d. (2010). Growth of bank deposits and its determinants: A pragmatic study on commercial banks. The IUP Journal of Financial Economics, 7(1), 52-65.

Audu, M. A., Oghoyone, A. S., \& Gulani, M. G. (2015). The impact of target deposit mobilization on the banking industry: A study of selected banks in Maiduguri Metropolis. IOSR Journal of Business and Management, 17(5), 36-52. https://doi. org/10.9790/487X-17533652

Banna, H., Ahmad, R., \& Koh, E. H. Y. (2017). Determinants of Commercial Banks' Efficiency in Bangladesh: Does Crisis Matter? Journal of Asian Finance, Economics and Business, 4(3), 19-26. http://dx.doi.org/10.13106/jafeb.2017.vol4.no3.19

Giao, H. N. K. (2019). Customer Satisfaction towards ATM Services: A Case of Vietcombank Vinh Long, Vietnam. Journal of Asian Finance, Economics and Business, 6(1), 141-148. http://doi.org/10.13106/jafeb.2019.vol6.no1.141

Giao, H. N. K., \& Vuong, B. N. (2019). Master Curriculum High School Business Research Methods: Updated SmartPLS. Ho Chi Minh, Vietnam: Financial Publishing House.

Giao, H. N. K., Vuong, B. N., Huan, D. D., Tushar, H., \& Quan, T. N. (2020). The effect of emotional intelligence on turnover intention and the moderating role of perceived organizational support: Evidence from the banking industry of Vietnam. Sustainability, 12(5), 1857. https://doi.org/10.3390/su12051857

Jaber, A. S., \& Manasrah, M. S. (2017). The factors that affect to attract deposits in Palestinian Islamic banks. Asian Journal of Finance \& Accounting, 9(1), 261-273. http://dx.doi. org/10.5296/ajfa.v9i1.11020

Kieu, N. M. (2009). Commercial banking. Ho Chi Minh, Vietnam: Statistical Publishing House.

Krisnanto, U. (2011). The customers' determinant factors of the bank selection. International Research Journal of Business Studies, 4(1), 59-70. https://doi.org/10.21632/irjbs.4.1.59-70

Lokesha, \& Hawaldar, I. T. (2019). Impact of factors on the utilization of agricultural credit of banks: an analysis from the borrowers' perspective. Banks and Bank Systems, 14(1), 181192. https://doi.org/10.21511/bbs.14(1).2019.16

Mushtaq, S., \& Siddiqui, D. A. (2017). Effect of interest rate on bank deposits: Evidences from Islamic and non-Islamic economies. Future Business Journal, 3(1), 1-8. https://doi.org/10.1016/j. fbj.2017.01.002

Tabash, M. I. (2019). An Empirical Investigation on the Relation between Disclosure and Financial Performance of Islamic Banks in the United Arab Emirates. Journal of Asian Finance, Economics and Business, 6(4), 27-35. https://doi.org/10.13106/ jafeb.2019.vol6.no4.27

van Dahm, K. (1995). Bank Management (3rd Ed.). London: The Dryden Press.

Vazifehdoost, H., Mohammadi, M. N., \& Shilan, J. M. (2015). Investigation and determination of factors which affect bank deposits and resources in Iranian banking industry. Mediterranean Journal of Social Sciences, 6(2), 672-675. https://doi.org/10.5901/mjss.2015.v6n2s1p672

Vuong, B. N., \& Giao, H. N. K. (2020). The Impact of Perceived Brand Globalness on Consumers' Purchase Intention and the Moderating Role of Consumer Ethnocentrism: An Evidence from Vietnam. Journal of International Consumer Marketing, 32(1), 47-68. https://doi.org/10.1080/08961530.2019.1619115

Vuong,B.N.,Hieu,V.T.,\&Trang,N.T.T.(2020).Anempiricalanalysis of mobile banking adoption in Vietnam. Gestão e Sociedade, 14, 3365-3393. https://doi.org/10.21171/ges.v14i37.3078

Vuong, B. N., \& Suntrayuth, S. (2020). The impact of human resource management practices on employee engagement and moderating role of gender and marital status: An evidence from the Vietnamese banking industry. Management Science Letters, 10(7), 1633-1648. https://doi.org/10.5267/j.msl.2019.12.003 